\title{
Disolución por pérdidas o solicitud de concurso voluntario: la alternativa legal en las sociedades de capital españolas
}

\author{
José Carlos Vázquez Cueto49 \\ Universidad de Sevilla, España \\ vcueto@us.es
}

Fecha de recibido: 2016 / Fecha de aprobación: 2016

\section{Resumen}

El presente trabajo trata sobre el conflicto normativo que se presenta en el Ordenamiento jurídico español en los supuestos de grave crisis empresarial de las sociedades de capital entre la solución prevista por el Derecho de sociedades (la disolución) y la que dispone el Derecho concursal (la petición de concurso de acreedores). Tal conflicto pone en juego el tema de la distribución de competencias entre los órganos sociales; un asunto de particular interés por lo que se refiere especialmente a los administradores, debido a la responsabilidad por deudas sociales a que pueden llegar a verse sometidos por la infracción de sus deberes legales en este punto.

\section{Palabras Clave}

Concurso de acreedores / disolución / sociedades de capital / administradores sociales / responsabilidad por deudas sociales

This paper deals with the conflict which sets out in Spanish Law in situations of serious economic crisis of companies with limited liability between the answer of the Company Law (dissolution) and the solution of the Insolvency Law (request for a declaration opening the insolvency proceedings). That conflict suggests the question of the distribution of powers inside the company; an interesting issue specially for the directors, due to the liability for company debts that could fall to them because of the offense of their legal duties.

insolvency proceeding / dissolution / companies with limited liability / directors / liability for company debts

${ }^{49}$ Doctor en Derecho por la Universidad de Sevilla, Catedrático de Derecho Mercantil de la Universidad de Sevilla (desde febrero 2016) y Director del Departamento de Derecho Mercantil de la Universidad de Sevilla (desde octubre de 2013). 


\section{Tabla de Contenido}

I. Introducción. Presentación del problema. II. Breve descripción de las disposiciones normativas en conflicto. I. La insolvencia de la sociedad de capital y su solicitud de concurso de acreedores.- 2. El desajuste patrimonial grave de la sociedad como causa legal de su disolución. 2.I. La fijación de unas causas legales de disolución de las sociedades de capital. 2.2. La disolución por pérdidas en concurrencia con la insolvencia. 3. Las cuestiones por resolver. Planteamiento. III. Ensayo de una propuesta interpretativa. I. La fijación de una serie de afirmaciones como punto de partida para resolver los interrogantes planteados. 2. Una propuesta de solución ante la alternativa legal entre la disolución social y el concurso. IV. La interferencia del artículo 5-bis de la ley concursal en el ámbito de aplicación de la disciplina. Lista de referencias ${ }^{50}$

\section{Introducción. Presentación del problema}

Las situaciones de crisis empresariales extremas de las sociedades de capital son objeto de tratamiento por el Derecho concursal, pero también suelen preocupar al Derecho de sociedades. Por lo que hace a la primera de estas dos parcelas normativas, resulta normal que se reserve a la propia deudora la posibilidad de instar directamente, a través de alguno de sus órganos, una resolución de la autoridad competente mediante el que se ponga en marcha el procedimiento concursal, que puede acabar provocando la liquidación y extinción de la entidad. Pero también sucede con relativa asiduidad que la regulación específicamente dictada para dichas formas sociales contemple asimismo una serie de dispositivos societarios de alerta ante tales situaciones. Unos dispositivos de los que resulta un deber de toma de decisiones en su seno, cuya inobservancia (responsabilidades aparte) puede dar pie a otro tipo de resoluciones de la autoridad competente que coloque igualmente a la sociedad en la rampa de salida hacia su desaparición del tráfico.

Los supuestos de hecho que legalmente permiten verificar una situación de crisis desencadenante de una o de otra reacción legislativa no tienen por qué ser idénticos. Aunque, en buena lógica, guardarán un acusado parentesco entre ellos, por tratarse en todo caso de situaciones que hacen dudar con fundamento de la capacidad de la sociedad para atender el pago a sus acreedores y de la rentabilidad a futuro de la inversión efectuada en su momento por los socios. Pero, incluso en los casos de falta de identidad, no resulta en absoluto extraño que en la realidad diaria se simultaneen los presupuestos objetivos que provocan la entrada en juego de las soluciones previstas en el Derecho concursal y en el Derecho de sociedades, dando así origen a un conflicto entre normas que pone de relieve, como en

\footnotetext{
${ }^{50}$ Este trabajo ha sido elaborado en el marco del Proyecto I+D «Crisis empresariales: prevención, tratamiento y solución desde el Derecho concursal y el Derecho de sociedades» (DER2014-55427-C2-1-P), perteneciente al Programa Estatal de Fomento de la Investigación Científica y Técnica de Excelencia, del Ministerio de Economía y Competitividad del Gobierno de España, y del que el autor es su Investigador Principal.
} 
ninguno otro, por exigencias de seguridad jurídica, la necesidad de que el legislador establezca los oportunos mecanismos de coordinación entre estas dos áreas de regulación.

El Derecho español es un claro exponente de cuanto se ha descrito. La legislación concursal española atribuye al órgano de administración de la sociedad la competencia para instar su concurso de acreedores, en atención a un deber legal o por decisión discrecional, según los casos, cuando se da el presupuesto objetivo para ello, calificado como “insolvencia" (arts.2, 3.I y 5 Ley 22/2003, de 9 de julio, Concursal -LCo, de ahora en adelante-). Pero, simultáneamente, cuando se trata de sociedades de capital $^{51}$ en situación de desbalance grave ${ }^{52}$, la legislación societaria específica requiere de ese mismo órgano de administración la adopción de otra serie de medidas so pena de disolución judicial (arts.363 a 367 Texto Refundido de la Ley de Sociedades de Capital, aprobado mediante RDLeg I/2010, de 2 de julio -TRLSC, en lo sucesivo- $)^{53}$. Surge por consiguiente la duda en torno a la secuencia de actuaciones a

${ }^{51}$ En España, los tipos societarios capitalistas son la sociedad anónima, la sociedad de responsabilidad limitada o sociedad limitada (funcionalmente análoga a la sociedad colectiva de responsabilidad limitada en Nicaragua) y la sociedad comanditaria por acciones, reguladas en el Texto Refundido de la Ley de Sociedades de Capital. También este texto completa la regulación de otro tipo capitalista, pero que debe considerarse de condición comunitaria, antes que española: la sociedad anónima europea o sociedad europea (SE) domiciliada en España, regulada fundamentalmente mediante el Reglamento (CE) $n^{\circ}$ 2157/2001 del Consejo, de 8 de octubre de 2001 (publicado en el n²94 del Diario Oficial de la Unión Europea, de 10 de noviembre).

${ }^{52}$ Con los términos "desbalance contable" o "déficit contable" pretendemos aludir al desajuste que arroja el balance de ejercicio de una sociedad de capital derivado de la existencia de un neto patrimonial inferior a la cifra del capital social estatutario. Cuando tal desequilibrio asciende a más de la mitad del capital social la sociedad se considera en causa de disolución legal por pérdidas [art.363.1 e) TRLSC]. La citada causal de la legislación española vendría a corresponderse, mutatis mutandis (y son abundantes las diferencias de régimen entre uno y otro Ordenamiento en cuanto al procedimiento conducente a la disolución y a las responsabilidades en juego), con la recogida en el art.271 del Código de Comercio de la República de Nicaragua, de 30 de abril de 1914 (CCN, en lo sucesivo), conforme al que "[L]os acreedores de una sociedad anónima podrán exigir su disolución, probando que posteriormente a la época de sus contratos, la mitad del capital social se ha perdido; pero la sociedad podrá oponerse a la disolución siempre que preste las garantías necesarias para el pago a sus acreedores". Naturalmente, siendo el capital el último baluarte de retención de una porción mínima de patrimonio libre de deudas, la "pérdida" de su mitad significa tanto como la existencia de un desequilibrio patrimonial negativo de idéntica cuantía, cuya ocultación a la hora de contratar con terceros en el tráfico (derivado del hecho de que la cifra formal de capital siga incólume) habría supuesto defraudar significativamente la confianza depositada en la sociedad. De ahí la facultad reconocida a los acreedores.

Hay que recordar, por otro lado, que esta causa de disolución no se da en las sociedades de personas, probablemente por las dos siguientes circunstancias: porque se trata de tipos sociales cuyas deudas pueden llegar a comunicarse hasta el patrimonio personal de los socios, lo que significa una garantía añadida ante un eventual empobrecimiento patrimonial de la sociedad; y porque en ellas (salvo que sean de duración determinada) cualquier socio puede instar y obtener una disolución social, ad nutum y sin mala fe, sin necesidad de que se alcance un acuerdo mayoritario ni mucho menos contar con el consentimiento del resto de la masa social.

${ }^{53}$ La Ley Concursal se publicó en el Boletín Oficial del Estado (BOE) n ${ }^{\circ} 164$, de 10 de julio de 2003. E1 Texto Refundido de la Ley de Sociedades de Capital en el BOE nº161, de 3 de julio de 2010. Una versión de libre acceso actualizada y consolidada, aunque no oficial, de estas y de otras disposiciones normativas españolas y provenientes de la UE puede encontrarse en la página Web del BOE: 
tomar en el caso, nada infrecuente, de que la sociedad se halle simultáneamente en insolvencia y desbalance: si las medidas dispuestas por ambas regulaciones son compatibles entre sí; en caso afirmativo, si han de adoptarse todas ellas o basta con las de una de ellas; o, en otro caso, cuál debe ser la elegida.

Conviene advertir de que el legislador societario tomó desde un primer momento conciencia de la aparente disyuntiva que provocaba la confluencia de ambas disciplinas y de la necesidad de fijar un orden de actuación al respecto. Así, la promulgación del nuevo texto normativo concursal vino acompañada (en la misma Ley, en forma de Disposiciones Finales Vigésima -para las sociedades anónimas- y Vigésimoprimera -para las sociedades de responsabilidad limitada-) de una reforma en este punto de las leyes reguladoras de estos tipos sociales, por entonces vigentes ${ }^{54}$, que tenía muy presente la posibilidad de que la situación de desajuste contable grave encontrara solución a través de la solicitud de concurso de acreedores (cuando fuera "procedente"). Lo que ocurre es que la modificación introducida fue tan poco expresiva y sumamente ambigua que, más que resolver las dudas, ayudó a alimentar aún más la controversia. Y la verdad es que tal estado de la cuestión persiste con la vigencia del Texto Refundido de la Ley de Sociedades de Capital, pese al esfuerzo legislativo por aclarar este extremo, acentuado si cabe por un contexto económico de crisis que ya en el instante de su aprobación venía multiplicando en la realidad diaria los casos en que se verificaba la mencionada confluencia de supuestos de hecho.

Es preciso llamar la atención sobre la considerable importancia práctica que reviste la respuesta al problema planteado debido a las severas consecuencias jurídicas que pueden derivarse, no ya de la acertada elección de la concreta medida que corresponda, sino, lo que es más grave, del hecho de no haber acertado con la respuesta querida por el legislador en el caso concreto, o de no haber tomado ninguna medida al respecto. Téngase en cuenta que la actuación de la sociedad en este terreno no es completamente discrecional. Se halla fuertemente marcada por normas imperativas, ante cuya inobservancia pueden desencadenarse, como se verá en el apartado siguiente, efectos jurídicopatrimoniales nada deseables para la propia sociedad $y$, aún con mayor rigor si cabe, para sus administradores, cuyo patrimonio personal puede verse incluso comprometido en el pago de las deudas sociales.

https://www.boe.es/legislacion/legislacion.php.

${ }^{54}$ Aludimos al Texto Refundido de la Ley de Sociedades Anónimas (aprobado mediante Real Decreto Legislativo 1564/1989, de 22 de diciembre -BOE n 310 , de 27 de diciembre) y a la Ley de Sociedades de Responsabilidad Limitada (Ley 2/1995, de 23 de marzo -BOE ${ }^{\circ} 71$, de 24 de marzo), ambos derogados por el TRLSC. 


\section{Breve descripción de las disposiciones normativas en conflicto}

\section{La insolvencia de la sociedad de capital y su solicitud de concurso de acreedores}

La legislación española no conoce otro procedimiento concursal que el concurso de acreedores, regulado por la LCo, al que puede acogerse cualquier persona de naturaleza jurídico-privada (art. I LCo). Se trata de un expediente con una finalidad solutoria (mediante convenio de continuación o de reorganización con los acreedores o a través de la liquidación del patrimonio del deudor), no preventiva de la situación de crisis que lo desencadena, que la Ley fija en la insolvencia del deudor (art.2 LCo). La descripción de las dos perspectivas temporales desde la que el legislador contempla la situación de insolvencia (actual, como estado presente: art.2.2 LCo; inminente, como pronóstico fiable de devenir en tal estado en un futuro próximo: art.2.3 LCo) deja bien a las claras que el presupuesto objetivo único del procedimiento concursal español (también único) recae sobre una incapacidad de pago de deudas ya vencidas y exigibles, o de vencimiento cercano, mediante los mecanismos normales de satisfacción a los que suele acudirse en el tráfico, independientemente del motivo. Una situación crítica que puede ser reflejo o de algún otro modo coincidir, o no, con una insuficiencia patrimonial, esto es, con un pasivo superior al activo. Pero que no consiste propiamente en tal insuficiencia, sino en un descubierto de tesorería; en una falta consistente y persistente de liquidez para pagar, ahora o próximamente $^{55}$ (Vázquez, 2009).

La reacción del legislador español ante la insolvencia del deudor no es uniforme. El mismo deudor puede pedirlo del Juez del concurso si advierte que está en insolvencia inminente. Mas (art.5 LCo) debe hacerlo si está en insolvencia actual, "dentro de los dos meses siguientes a la fecha en que hubiera conocido o debido conocer su estado de insolvencia” (Rodríguez de Quiñones, 2016). En ambos casos la Ley cuida de fijar la oportuna atribución competencial en el supuesto del deudor persona jurídica (y, por lo tanto,

\footnotetext{
${ }_{55}$ Así, se halla en insolvencia actual "el deudor que no puede cumplir regularmente sus obligaciones exigibles" (art.2.2 LCo). Se encuentra en insolvencia inminente "el deudor que prevea que no podrá cumplir regular y puntualmente sus obligaciones" (art.2.3 LCo). Cfr., abundando en las ideas expresadas en el texto, lo que afirma el Tribunal Supremo español (Sala $1^{\text {a }}$, de lo Civil) en su Sentencia de 1 de abril de 2014: "No puede confundirse la situación de insolvencia que define el artículo 2.2 de la Ley Concursal cuando afirma que "se encuentra en estado de insolvencia el deudor que no puede cumplir regularmente sus obligaciones exigibles", con la situación de pérdidas agravadas, incluso de fondos propios negativos, que determinan el deber de los administradores de realizar las actuaciones que las leyes societarias les imponen encaminadas a la disolución de la sociedad y, que, en caso de incumplimiento de tales deberes, dan lugar por esa sola razón a su responsabilidad con arreglo a la legislación societaria.[JEn la Ley Concursal la insolvencia no se identifica con el desbalance o las pérdidas agravadas. Cabe que el patrimonio contable sea inferior a la mitad del capital social, incluso que el activo sea inferior al pasivo y, sin embargo, el deudor pueda cumplir regularmente con sus obligaciones, pues obtenga financiación. Y, al contrario, el activo puede ser superior al pasivo pero que la deudora carezca de liquidez (por ejemplo, por ser el activo ser liquidable a muy largo plazo y no obtener financiación) lo que determinaría la imposibilidad de cumplimiento regular de las obligaciones en un determinado momento y, consecuentemente, la insolvencia actual.]/Por consiguiente, aunque con frecuencia se solapen, insolvencia y desbalance patrimonial no son equivalentes, y lo determinante para apreciar si ha concurrido el supuesto de hecho del art. 165.1 de la Ley Concursal es la insolvencia, no el desbalance o la concurrencia de la causa legal de disolución por pérdidas agravadas". Las Sentencias del Tribunal Supremo español y buena parte de las de la "jurisprudencia menor", pueden consultarse en la página web de acceso libre del Consejo General del Poder Judicial (CENDOJ), en http://www.poderjudicial.es/search/indexAN.jsp.
} 
de las sociedades de capital): "será competente para decidir sobre la solicitud el órgano de administración o de liquidación" (art.3.I.2 LCo) ${ }^{56}$.

Obsérvese el esmero en el empleo de la terminología jurídica. No se trata de que los administradores lleven a la práctica o ejecuten una decisión ajena, presentando la solicitud formal ante el Juzgado competente en uso de sus facultades estrictamente representativas. Es la competencia en torno a la decisión misma de concursar la que se atribuye, no a la junta general de socios, sino al órgano de administración, que habrá de adoptarla conforme a su régimen de actuación, según la modalidad que revista de entre las legalmente permitidas (cfr. arts.210 y 233 LSC) ${ }^{57}$. Sin duda ha pesado en tal determinación legal el hecho de que, en definitiva, la apertura de un concurso supone la búsqueda de una solución para un problema de atención del pasivo con los activos disponibles. Un asunto que, por trascendente que pueda llegar a ser la solución final adoptada para el futuro de la entidad (hasta el extremo de que puede llevar a hacerla desparecer si el concurso acaba con liquidación insatisfactoria: art.178.3 LCo), no sale de la esfera natural de gestión social, que debe corresponder, salvo expresa encomienda legal a la junta general de socios, al órgano de administración (Rojo, 2004; Gallego, $2012 a)^{58}$.

${ }^{56}$ Este inciso desapareció tras la desafortunada reforma de la Ley Concursal incluida en la Ley 14/2013, de 27 de septiembre, de apoyo a los emprendedores y su internacionalización (BOE $\mathrm{n}^{\circ} 233$, de 28 de septiembre). Ha reaparecido, para despejar cualquier duda al respecto, con la modificación introducida por la Disposición Final 5.1 de la Ley 40/2015, de 1 de octubre, de Régimen Jurídico del Sector Público (BOE n²36, de 2 de octubre).

${ }^{57}$ Ello no significa, desde luego, que no pueda atribuirse el asunto estatutariamente a la junta de socios, en cuyo caso cabe entender que la solicitud carecería de valor como manifestación de la voluntad social mientras no se acreditara el correspondiente acuerdo favorable. O que no pueda haber instrucciones de este órgano asambleario al respecto, o un respaldo posterior específico, al amparo del art.161 LSC. Bien es cierto que la incidencia real ad extra del juego de este último precepto, tanto en el plano estrictamente societario como concursal, puede ser muy limitada (cfr., por ejemplo, el art.236.2 LSC, para el que "[E]n ningún caso exonerará de responsabilidad la circunstancia de que el acto o acuerdo lesivo haya sido adoptado, autorizado o ratificado por la junta general", y cuya interpretación más atendible parece ser la de que el mero hecho de contar con el apoyo de la junta general de socios no implica, de por sí, un quitus de las responsabilidad de los administradores por las decisiones tomadas en ejercicio de sus competencias).

${ }^{58}$ En la legislación nicaragüense se reconocen dos procedimientos concursales mercantiles: la suspensión de pagos y la quiebra. Pese a hallarse aparentemente dispuestos para situaciones distintas, al modo como venía establecido en el Código de comercio español de 1885 en su versión originaria (mera iliquidez la primera, insuficiencia patrimonial la segunda), no poseen presupuestos objetivos excluyentes entre sí, sino que, sobre el papel, se encuentran parcialmente solapados. Y ello porque la suspensión de pagos (cuya solicitud ha de ser acordada por la junta general de socios de la sociedad anónima, ex art.1052 CCN) se configura legalmente como un beneficio que no se concede a todo el que atraviesa dificultades de liquidez, lo que deja ante la situación de quiebra no solo a quien cesa en los pagos por insuficiencia patrimonial, sino igualmente al que lo haga por cualquier otra causa pero no pueda acogerse a aquel expediente (cfr. arts.1047 y ss. CCN, especialmente el art.1062). Sea como fuese, mientras no haya una divergencia de relieve entre los valores efectivos de los distintos componentes del patrimonio social y los que han de figurar en balance, la insuficiencia patrimonial de una sociedad reflejará en extremo la concurrencia de un desajuste contable grave, susceptible de provocar la causal de disolución prevista por el art.271 CCN. Lo que fuerza la presencia de un conflicto entre normas concursales y societarias ante una situación de crisis empresarial. Bien es cierto que dicho conflicto se ve atemperado por el hecho de que el legislador nicaragüense no coloca a ambas medidas (la disolución o la petición de apertura de un procedimiento concursal) ante la correspondiente 
En cualquier caso, sea en cumplimiento de un deber sea discrecionalmente adoptada la decisión, se estaría, de estimarse la petición, ante un concurso voluntario, lo que, en principio (art.40 LCo), asegura al deudor mantenerse en el ejercicio de las facultades de administración y disposición de su patrimonio, aunque sometido a intervención por la administración concursal (algo muy diferente a la suspensión en tal ejercicio que, sobre el papel, se dictaría si, en caso de insolvencia actual, se declarara el concurso necesario a instancias de otro legitimado activo para ello; señaladamente, cualquier acreedor).

Pero la desatención de ese deber legal de pedir el concurso podría acarrearle unas consecuencias jurídicas extraordinariamente severas. Si se llega a abrir la pieza de calificación del concurso (efecto que pende del tipo de solución que finalmente se alcance: cfr. art.167.I LCo), la ley (art.165.1.1 LCo) anuda a este incumplimiento una presunción legal (atacable) de culpabilidad (civil; el aspecto penal queda completamente al margen: cfr. art.163.2 LCo). La calificación del concurso como culpable puede venir acompañada de una serie de pronunciamientos verdaderamente penosos, especialmente en relación con los administradores de una sociedad concursada (los que formalmente lo fueran al declararse el concurso o lo hubieran sido durante los dos años anteriores, e incluso los administradores de hecho) que sean calificados "personas afectadas por la calificación" (arts. 172 y 172-bis LCo). Merece la pena destacar ahora los siguientes pronunciamientos (Vázquez, 20l4): la inhabilitación temporal (entre dos a quince años) para administrar patrimonios ajenos, incluido ser administrador de sociedades mercantiles, y para ejercer el comercio; la condena a indemnizar los daños y perjuicios causados; y la cobertura con su patrimonio personal del déficit que pudiera derivarse de una eventual liquidación patrimonial insatisfactoria para los acreedores. Es cierto que la catalogación como "personas afectadas por la calificación" no viene automáticamente adosada a la condición de administradores societarios, sino que el Juez del concurso deberá valorar el grado de contribución de cada uno de ellos en los hechos desencadenantes de la culpabilidad. Pero no cabe duda de que, proviniendo la culpabilidad del incumplimiento de un deber que la Ley impone al órgano de administración como tal, resultará difícil encontrar razones para excluir a alguno de sus miembros de aquel calificativo legal, a menos que se trate de un consejo que hubiera atribuido tales funciones a órganos delegados y la situación de incumplimiento del deber no se hubiera prolongado excesivamente ${ }^{59}$.

instancia de decisión societaria: la quiebra (o la suspensión de pagos) podrá ser pedida por la propia sociedad; más la disolución prevista en el art.271 CCN únicamente puede ser solicitada por los acreedores. ${ }^{59}$ La solicitud de concurso ante una situación de insolvencia no se halla formalmente incluida en la lista de asuntos indelegables del actual art.249-bis LSC (ni del art.529-ter LSC, en el caso de las sociedades anónimas cotizadas), aunque, por la trascendencia que reviste, tal vez pudiera considerarse integrada en la letra $b$ ) de aquel artículo: "[L]a determinación de las politicas y estrategias generales de la sociedad". En cualquier caso, la preceptiva reunión con relativa regularidad de un consejo de administración (cfr. art.245.3 TRLSC) haría inexcusable la pasividad de sus miembros no delegados si el incumplimiento del deber de pedir el concurso ante una situación de insolvencia se prolongara demasiado en el tiempo. 


\section{El desajuste patrimonial grave de la sociedad como causa legal de su disolución}

\section{I. La fijación de unas causas legales de disolución de las sociedades de capital}

La disolución supone el punto de arranque del proceso naturalmente conducente a la desaparición de una sociedad del tráfico. Un punto de arranque que puede venir determinado por la Ley a la vista de determinadas circunstancias (la denominada "disolución de pleno derecho", como pudiera ser el transcurso del término de duración previamente fijado en sus estatutos sociales, sin que anterioridad se hubiera acordado su prórroga) o que puede dejarse a la decisión de instancias de poder de la propia sociedad (señaladamente, de su junta general) o, excepcional o supletoriamente, exógenas (de la autoridad judicial). La decisión social puede venir adoptada discrecionalmente sin necesidad de acogerse a motivo alguno que así lo predisponga. Pero resulta mucho más frecuente en la realidad diaria que venga motivada por la concurrencia de alguno de los supuestos de hecho que la ley reguladora de las sociedades de capital españolas reconoce como causas legales de disolución o causas de disolución forzosa (cfr. art.363.I TRLSC).

Las causas legales de disolución recogen un conjunto de circunstancias anómalas que representan una sensible alteración de los presupuestos o los fundamentos bajo los que los socios se aprestaron a fundar la sociedad en su momento, y que, en buena lógica, deberían hacerlos replantearse la oportunidad o la funcionalidad de mantenerla en vida, máxime cuando su continuidad, tal cual se halla, supone antes que nada una amenaza para el tráfico, bien sea por traicionar la confianza de que se está ante una entidad plenamente operativa, bien sea por poner en riesgo las garantías de contar con la solidez patrimonial precisa para hacer frente a los compromisos adquiridos o por adquirir ante terceros.

Con todo, su juego no consiste de entrada en eliminar a la sociedad del tráfico o en imponer a sus órganos de decisión que lo decidan. Aunque la sociedad no sea capaz de tomar decisiones para su funcionamiento ordinario (por bloqueo en sus órganos, especialmente en su junta general), no explote de facto (cese en la actividad) o no pueda explotar ya su objeto (por imposibilidad o conclusión), o vea disminuido su patrimonio libre de deudas por una acumulación de pérdidas considerable (por encima de la mitad de su cifra de capital) o por una reducción de la cifra formal que le sirve de barrera por debajo de lo que el propio legislador declara admisible (por debajo de la cifra de capital mínimo), el legislador se muestra sumamente respetuoso con el principio de libertad de empresa $y$, comoquiera que es de suponer que la situación, de por sí, aún no tiene por qué significar una efectiva incapacidad para atender el pasivo a medida que se vaya haciendo exigible, permite que sea la propia entidad la que ponga solución al problema (Uría, Menéndez \& Beltrán, 1998). Las causas de disolución legales son, por consiguiente, ante todo, causas de reunión forzosa de la junta general de socios y de adopción de algún tipo de decisión que ponga fin a la situación en la que se halle la sociedad, ya sea apostando por su continuidad (removiendo la causa), ya sea optando por su desaparición del tráfico (disolviéndose efectivamente). De hecho, la Ley pone su acento más que nada en la actuación del órgano de administración, que, por su privilegiada posición al frente de la llevanza social, debe ser quien advierta a tiempo la concurrencia de alguna de esas causales y tome la iniciativa en la adopción de medidas. Por ello, la Ley requiere que en un plazo de dos meses (desde que se apreciara o debiera estarse en disposición de apreciar la causa) el órgano de administración convoque la junta y le proponga la solución 
a su entender preferible (art.365 LSC). Bien es cierto que no debería haber dudas para admitir una salida distinta a la situación, de modo que, en vez de proceder a esa convocatoria, dicho órgano procurara y obtuviera una reunión universal de la junta (art.I78 TRLSC), o, más aún, procediera por sí mismo a acometer alguna actuación que removiera de facto la causa de disolución (verbigracia, en el caso de la disolución por acumulación de pérdidas, si enajenara un activo "no esencial" que generara una plusvalía que cubriera el desajuste contable; o si obtuviera un préstamo participativo en las condiciones en que se considera contablemente un componente más del patrimonio neto: cfr. Real Decreto-Ley 7/1996, de 7 de junio, de Medidas urgentes de carácter fiscal y de fomento y liberalización de la actividad económica; $\mathrm{BOE} \mathrm{n}^{\circ} \mathrm{I39}$, de 8 de junio).

La disolución social solo se convierte en una medida forzosa si la junta general no adopta ningún acuerdo que ponga fin a la concurrencia de la causal o que le dé curso mediante el acuerdo de disolución correspondiente. En ese caso es el propio órgano de administración el que, en los dos meses siguientes a la fecha de la reunión prevista (o celebrada) debe (cualquier interesado también puede hacerlo) instarla del Juez de lo Mercantil del domicilio social (dando inicio a un expediente que, pese a la dicción del art.366.I, in fine, TRLSC, conforme al que la solicitud "deberá dirigirse contra la sociedad", pertenece actualmente, por disposición legal, al ámbito de la jurisdicción voluntaria, como se establece en los arts. 125 a 128 Ley I5/20I5, de 2 de julio, de Jurisdicción Voluntaria-LJV-; BOE n I58, de 3 de julio). El carácter coercitivo de las actuaciones impuestas a los administradores encuentra su punto culminante en las rigurosas consecuencias jurídicas que se establecen para el caso de que no se proceda a convocar la junta o a instar la disolución judicial en los plazos bimensuales dispuestos: la responsabilidad solidaria ante los acreedores por las deudas sociales nacidas con posterioridad al acaecimiento de la causa legal de disolución (art.367 TRLSC).

\subsection{La disolución por pérdidas en concurrencia con la insolvencia}

De entre todas la causas de disolución es la que consiste en un desajuste contable propiciado por una acumulación de pérdidas que dejan el patrimonio neto de la sociedad por debajo de la mitad del capital social [art.363.I.e) TRLSC] la que reviste, sin duda alguna, mayor relevancia práctica y la que, a la postre, está dando origen en la mayoría de los casos al nacimiento de la responsabilidad legal por deudas debida al incumplimiento de la ley. Fundamentalmente por dos motivos:

- porque la persistencia de una crisis económica tan aguda como la que se viene padeciendo en España de unos años a esta parte ha ido erosionando poco a poco los excedentes que las sociedades acumulaban en sus patrimonios como consecuencia de beneficios anteriores;

- y por la tradicional predilección en España por la constitución de sociedades pobremente capitalizadas (justo en el capital mínimo legal: 3000 euros para el caso de una sociedad de responsabilidad limitada ${ }^{60}$ ),

${ }^{60}$ Para formarse a una idea, según el Anuario de Estadística Mercantil 2015 publicado por el Colegio de Registradores de España (disponible en formato pdf en la web http:www.registradores.org/portalestadistico-registral/estadisticas-mercantiles), en el mencionado año un $55 \%$ de las sociedades de responsabilidad limitada constituidas en España se fundaron con un capital de 3000 euros, mientras que 
que, por lo tanto, entran con gran facilidad en c ausa de disolución por pérdidas en cuanto registren una tendencia económica ligeramente desfavorable (para ser exactos, en estos casos de capital mínimo, en cuanto acumulen I500,0I euros de pérdidas).

Probablemente por ello, y también porque, sin duda alguna, se trata del motivo más íntimamente conectado, tanto jurídica como económicamente, con la situación de insolvencia, la irrupción de la solicitud de concurso entre las opciones lícitamente disponibles para salir de la situación anómala en que se ve la sociedad se ha producido desde sus orígenes (esto es, desde la promulgación de la Ley Concursal, como anteriormente se dijo) vinculada exclusiva ( $y$, cabe entender, excluyentemente ${ }^{61}$ ) a esta causal. Lo que sucede es que, como asimismo se ha avanzado, la inclusión de esta opción en la secuencia de acontecimientos que sucede a la verificación del desajuste contable tipificado como causa de disolución no ha sido muy afortunada, pues más que dar respuesta al problema latente del conflicto entre la medida societaria y la concursal, ha incrementado la confusión y la inseguridad jurídica en torno al asunto. Paso muy resumidamente a comentar los diferentes hitos destacables a estos efectos, antes de ofrecer una posible solución interpretativa.

Por lo pronto, en el momento de la aparición de la Ley Concursal llamó la atención poderosamente que las modificaciones introducidas en las (entonces vigentes; hoy sustituidas por el TRLSC) leyes de sociedades anónimas y de sociedades de responsabilidad limitada para dar paso, expresamente, a la petición de concurso como opción neutralizadora de la disolución no fueran idénticas. No se acierta a comprender el motivo, porque las relativas diferencias en la configuración tipológica de ambas formas sociales en absoluto justificaban un tratamiento distinto de la inclusión del concurso entre las medidas a adoptar. Pero lo cierto es que, aunque parecidas, las redacciones no coincidían. Y, lo que es peor, pese a su notoria ambigüedad, daban la impresión de querer haber previsto soluciones sustantivamente distintas (Alcover, 2006).

La nueva redacción dada a la mera formulación de la causal en ambas disposiciones normativas sí era coincidente: había que poner en marcha el mecanismo societario de emergencia "[P]or consecuencia de pérdidas que dejen reducido el patrimonio neto a una cantidad inferior a la mitad del capital social, a no ser que éste se aumente o se reduzca en la medida suficiente, y siempre que no sea procedente solicitar la declaración de concurso conforme a lo dispuesto en la Ley 22/2003, de 9 de julio, Concursal" [arts.260.1.4 ${ }^{\circ}$ TRLSA y 104.I. e) LSRL; bien es cierto que sin aclarar si la procedencia de la solicitud se debía a que hubiera insolvencia -actual o inminente- o a que existiera el deber de pedir el concurso -en cuyo caso solo existiría de haber insolvencia actual-]. Pero a la hora de regular la actuación que deriva de la constatación de la causa se ponían de relieve discrepancias importantes. El art.262.2 TRLSA parecía dar a entender que la petición de concurso constituía una alternativa para el órgano de administración de

otro 34\% con un capital entre 3000 y 12000 euros. Por otro lado, no parece que la situación en Nicaragua deba ser menos preocupante, pues la ausencia, con carácter general, de un capital mínimo legal en la sociedad anónima incrementará la exposición a una situación de causa de disolución por pérdidas en cuanto nos hallemos ante una coyuntura económica desfavorable.

${ }^{61}$ Con ello quiero expresar que, en caso de concurrencia de la insolvencia con otra de las restantes causales de disolución, el recurso a la solicitud de concurso, aunque lícito y posible, no enervará el deber del órgano de administración de reunir a la junta y acordar la disolución u otra medida que la remueva, so pena de verse incurso en la responsabilidad del art.367 TRLSC. 
la sociedad anónima, que desactivaba el deber de convocar la junta general para acordar la disolución o la remoción de la causa ${ }^{62}$; lo que resultaba congruente con el tenor del art.3.I.2 LCo, que atribuía la decisión sobre esta petición a dicho órgano. Sin embargo, tal congruencia quedaba en el aire ante lo dispuesto por el art.262.5, in fine, TRLSA, que vinculaba la responsabilidad por las deudas sociales de los administradores al incumplimiento del deber de instar el concurso "en el plazo de dos meses a contar desde la fecha prevista para la celebración de la junta, cuando ésta no se haya constituido, o desde el día de la junta, cuando el acuerdo hubiera sido contrario a la disolución o al concurso" (el subrayado es mío), referencia esta última aparentemente contradictoria con lo anterior. La LSRL, en cambio, parecía partir de la base de que esta decisión de acudir al concurso, en vez de disolver, quedaba reservada a la junta general de la sociedad limitada ${ }^{63}$, si bien, a diferencia del TRLSA, no conectaba literalmente la responsabilidad de los administradores al hecho de que hubiera habido un acuerdo de la junta general "contrario al concurso"64.

Este estado de cosas legislativo persistió sustancialmente así hasta la aprobación del Texto Refundido de la Ley de Sociedades de Capital. Únicamente cabe destacar la reforma introducida en el art. I05.5 LSRL (en virtud de la Ley 19/2005, de 14 de noviembre, sobre la sociedad anónima europea domiciliada en España-BOE n`273, de 15 de noviembre-) para equiparar el párrafo relativo a la responsabilidad por deudas de los administradores al establecido para las sociedades anónimas por el art.262.5 TRLSA, con lo que (aparte de limitarla a las deudas nacidas tras la causa de disolución), se constreñía formalmente los supuestos de dicha responsabilidad a los casos de ausencia de convocatoria de la junta general para que acordara la disolución y a los de pasividad ante la no celebración de la junta o ante el acuerdo de la junta contrario a la "disolución o al concurso". Un cambio coherente con el hecho, ya destacado, de que la LSRL no contemplara la petición de concurso como una opción inicial de los administradores, sino como una medida alternativa a la disolución que debía proponerse ante los socios para que estos adoptaran el acuerdo correspondiente. Pero que, como también se ha resaltado, contrastaba con lo dispuesto para las sociedades anónimas en el art.262.2.2 TRLSA.

La aparición del Texto Refundido de la Ley de Sociedades de Capital buscó una respuesta uniforme para ambos tipos sociales conciliadora de las soluciones hasta entonces divergentes del TRLSA y de la LSRL,

${ }^{62}$ Cfr. art.262.2 TRLSA, en la redacción resultante de la DF Vigésima LCo: "[L]os administradores deberán convocar Junta General en el plazo de dos meses para que adopte el acuerdo de disolución [...]. Asimismo podrán solicitar la declaración de concurso por consecuencia de pérdidas que dejen reducido el patrimonio neto a una cantidad inferior a la mitad del capital social, a no ser que éste se aumente o se reduzca en la medida suficiente, siempre que la referida reducción determine la insolvencia de la sociedad, en los términos a que se refiere el artículo 2 de la Ley 22/2003, de 9 de julio, Concursal".

${ }^{63}$ Cfr. art.105.1 LSRL, en la redacción resultante de la DF Vigésimoprimera LCo: "[E]n los casos previstos en los párrafos c) a g) del apartado 1 del artículo anterior, la disolución, o la solicitud de concurso, requerirá acuerdo de la Junta General adoptado por la mayoría a que se refiere el apartado 1 del artículo 53 . Los administradores deberán convocar la Junta General en el plazo de dos meses para que adopte el acuerdo de disolución o inste el concurso. Cualquier socio podrá solicitar de los administradores la convocatoria si, a su juicio, concurriera alguna de dichas causas de disolución, o concurriera la insolvencia de la sociedad, en los términos a que se refiere el artículo 2 de la Ley Concursal" (los subrayados son míos).

${ }^{64}$ Cfr. art.105.5 LSRL, en la redacción resultante de la DF Vigésimoprimera LCo: "[E]l incumplimiento de la obligación de convocar Junta General o de solicitar la disolución judicial o, si procediera, el concurso de acreedores de la sociedad determinará la responsabilidad solidaria de los administradores por todas las deudas sociales". 
cumpliendo de este modo con su cometido (constitucionalmente delimitado, ex art.82.5 Constitución Española de 1978) de "regularización, aclaración y armonización" de los textos legales preexistentes. Sin embargo, que la respuesta fuera uniforme no significa que fuera clara y coherente con los preceptos concordantes de la Ley Concursal.

El Texto Refundido mantiene sin cambios de calado la formulación general de la causa de disolución [art.363.I e) TRLSC ${ }^{65}$ ], que queda enervada si resulta "procedente" pedir el concurso. Sí que modifica la articulación de esta solicitud y su juego en la actuación que toca llevar a cabo al órgano de administración de las sociedades de capital. Y lo hace siguiendo, aparentemente, un criterio mixto (por no decir indefinido), pues lo que en una parte parece ser una concesión a la idea supuestamente expresada por el régimen de la sociedad de responsabilidad limitada, en otra da la impresión de inclinarse por el sistema pretendidamente querido para la anónima.

Así, por un lado, el acercamiento al régimen de la sociedad de responsabilidad limitada podría considerarse notorio, pues, aunque con una redacción diferente, parece reconocerse de un modo expreso que dicha solicitud de concurso debía ser propuesta a los socios para que fueran estos los que la acordaran en junta general en vez de optar por la disolución o por alguna medida que removiera la causa. Así, el art.365.I TRLSC reza: "[L]os administradores deberán convocar la junta general en el plazo de dos meses para que adopte el acuerdo de disolución o, si la sociedad fuera insolvente, ésta inste el concurso $[. .$.$] .Cualquier socio podrá solicitar de los administradores la convocatoria si, a su juicio, concurriera$ alguna causa de disolución o la sociedad fuera insolvente" (los subrayados son míos). Ahora bien, más adelante puede llegarse a pensar que la versión introducida por el TRLSC no contempla un eventual acuerdo de la junta general sobre la solicitud de concurso como salida al problema, puesto que un acuerdo de los socios contrario al concurso resulta, a tenor del texto de la Ley, irrelevante a efectos de desencadenar el deber de los administradores de instar la actuación judicial. Lo determinante es que no haya acuerdo sobre la disolución (ni ninguno otro que neutralice la causa, es de suponer) o que este sea "contrario". En este sentido, el art.366.2 TRLSC dispone: "[L]os administradores están obligados a solicitar la disolución judicial de la sociedad cuando el acuerdo social fuese contrario a la disolución o no pudiera ser logrado[...].La solicitud habrá de formularse en el plazo de dos meses a contar desde la fecha prevista para la celebración de la junta, cuando ésta no se haya constituido, o desde el día de la junta, cuando el acuerdo hubiera sido contrario a la disolución o no se hubiera adoptado" (los subrayados son míos). Y, por su parte, el art.367.I añade: "[R]esponderán solidariamente de las obligaciones sociales posteriores al acaecimiento de la causa legal de disolución los administradores que incumplan la obligación de convocar en el plazo de dos meses la junta general para que adopte, en su caso, el acuerdo de disolución, así como los administradores que no soliciten la disolución judicial o, si procediere, el concurso de la sociedad, en el plazo de dos meses a contar desde la fecha prevista para la celebración de la junta, cuando ésta no se haya constituido, o desde el día de la junta, cuando el acuerdo hubiera sido contrario a la disolución" (el subrayado es mío).

${ }^{65}$ Art.363.1.e) TRLSC: "[L]a sociedad de capital deberá disolverse[...] e). Por pérdidas que dejen reducido el patrimonio neto a una cantidad inferior a la mitad del capital social, a no ser que éste se aumente o se reduzca en la medida suficiente, y siempre que no sea procedente solicitar la declaración de concurso". 


\section{Las cuestiones por resolver. Planteamiento}

En definitiva, la ceremonia de la confusión que derivaba de la lectura de las normas dedicadas al asunto por el TRLSA y LSRL queda aliviada por el TRLSC en lo que toca a la eliminación de la disparidad de regímenes según el tipo social de que se tratara, lo que resultaba francamente inexplicable. Pero persiste en la correcta inteligencia que deba otorgarse a las normas -ahora uniformes para los dos tiposrelativas a la actuación que cabe exigir o que pueden acometer los dos órganos sociales ante la concurrencia de pérdidas que dejan el patrimonio por debajo de la mitad del capital social junto con una incapacidad de pago reveladora de insolvencia. Lo que, por encima de cualquier otra consideración, supone un motivo más que justificado de inquietud en quienes se ocupan de las labores de administración de las sociedades de capital, debido a la severa responsabilidad en juego. Por si fuera poco, la situación se ve agravada (igual que sucedía bajo la vigencia del TRLSA y la LSRL) en el momento en que se intenta coordinar de algún modo el TRLSC con los dictados de la Ley Concursal, especialmente de los que reservan al órgano de administración la decisión sobre la solicitud de concurso y los que distinguen entre insolvencia actual e inminente a efectos de fijar o no un deber de pedir el concurso dentro de un plazo también bimensual (arts.2 y 5 LCo). Un deber cuya inobservancia, no se olvide, puede tener graves consecuencias para la sociedad y a su vez, en caso de apertura de la sección de calificación, para los administradores.

A modo de síntesis, las incertidumbres de mayor enjundia se centran, fundamentalmente, en los siguientes puntos:

-Ante todo, el interrogante principal estriba en determinar si la entrada en juego de las reglas establecidas en los arts.363 y ss del TRLSC en relación con el concurso de acreedores se produce en cualquier supuesto de insolvencia, solo cuando la insolvencia es actual, o, en cambio, únicamente si es inminente.

- Ha de contestarse de igual modo a la cuestión relativa a la relación existente entre los plazos de cumplimiento de los deberes impuestos a los administradores por la legislación societaria (dos meses para convocar la junta general y, después, dos meses para instar la declaración judicial correspondiente) y del deber de pedir el concurso previsto en el art.5 LCo (dos meses desde que el deudor "hubiera conocido o debido conocer su estado de insolvencia"; dicho de otro modo; cómo pueden conciliarse dos plazos que coinciden en su duración (dos meses), pero que no tienen por qué hacerlo (es más, difícil será que lo haga) en el dies a quo para su cómputo.

- Hay que encontrar también la forma de cohonestar armónicamente las dos medidas fundamentalmente dispuestas ante la situación de crisis: la disolución judicial y el concurso. En este punto, es preciso resolver si la presencia de ambas medidas se configura verdaderamente como una disyuntiva o si son complementarias; si, para que los administradores salven su responsabilidad ex art.367 TRLSC, el orden del día de la junta convocada debe proponer las dos, o basta con una previamente seleccionada (y cuál de ellas debe considerarse preferente, en su caso); o si puede el órgano de administración dejar zanjado por completo el asunto acudiendo, sin necesidad de recabar apoyo alguno de la junta general, a una solicitud de concurso de acreedores. 
Tampoco acaba de ser suficientemente clara la Ley a la hora de fijar cuáles son los supuestos de hecho que desencadenan el deber de los administradores de instar la actuación judicial, así como de qué actuación judicial se está hablando para evitar la responsabilidad del art.367 TRLSC. En otras palabras: el alcance preciso que cabe atribuir en este contexto a la expresión legal "cuando el acuerdo hubiera sido contrario a la disolución o no se hubiera adoptado" (art.366.2, in fine, TRLSC), así como si pueden los administradores elegir indistintamente entre la disolución judicial o la petición de concurso, o hay una solución distinta para cada supuesto según las circunstancias que concurran; cuándo "procediere" pedir el concurso de la sociedad, y si esa "procedencia" del art.367.I TRLSC hace alusión a los mismos supuestos a los que se refiere el art.363.I e) al detallar las causas de disolución legal, habida cuenta de que las condiciones reinantes pueden haber cambiado de un momento a otro.

-Debe precisarse asimismo si es posible que la junta general o el órgano de administración, en solitario, acudan a alguna otra fórmula distinta de la disolución o de la petición de concurso pasa arreglar el desajuste contable y la situación de insolvencia, salvando al paso la responsabilidad de los administradores ex art.367 LSC.

-Cabe plantearse también cuáles pueden ser las consecuencias jurídicas de que la autoridad judicial desestime la petición formulada por la sociedad, en primera instancia o por vía de recurso, por considerar que no había causa de disolución, o que no había insolvencia, según los casos. O de que se declare nulo el acuerdo adoptado al efecto por la junta general de la sociedad, previa impugnación del mismo. En concreto, interesaría conocer los efectos de tales hipótesis sobre la responsabilidad de los administradores ex art.367 TRLSC.

-Por último, debe responderse a la pregunta sobre si la adopción de alguna de las medidas legalmente previstas por la sociedad resuelve el problema definitivamente, o si puede volver a reproducirse aunque la medida inicialmente seguida no haya dejado de producir sus efectos. Es decir, si se puede pedir el concurso tras haberse acordado o solicitado judicialmente la disolución; o si debe volver a plantearse el tema de la disolución si, estando la sociedad en concurso, se aprecia que el patrimonio neto se halla por debajo de la mitad del capital social.

\section{Ensayo de una propuesta interpretativa}

\section{La fijación de una serie de afirmaciones como punto de partida para resolver los interrogantes planteados}

Como se observa, son tantos y de tanta enjundia los interrogantes planteados que difícilmente puede encontrarse una respuesta articulada pacífica que satisfaga todos y cada uno de ellos y que, a la par, cuente con un respaldo específico en la letra de los preceptos dedicados por la legislación española a la materia, una vez puestas de manifiesto las aparentes incongruencias y las notorias lagunas que esta presenta. Buena prueba de ello es la división reinante entre los mercantilistas españoles que han estudiado la cuestión al hilo de las diferentes reformas legislativas que ha padecido la regulación 
societaria sobre las causas de disolución (Rojo, 2004; Beltrán, 2004; Alcover, 2006; Sequeira, 2009; Bataller, 20I la; Bataller, 20I Ib; Gallego, 20I2b; Pulgar, 20I2; Megías, 20I5).

Es preciso, por lo tanto, partir de que la solución a estos interrogantes solo puede venir de la mano de una interpretación sistemática de las normas que puede no agarrarse escrupulosamente al texto literal de la ley, cuyo entendimiento deberá matizarse en ocasiones para poder conciliarse con el fundamento de las instituciones en juego (la disolución social y el concurso de acreedores), y con las razones que llevan a concluir la oportunidad o necesidad de acudir a ellas ante la situación económica de la sociedad (desajuste contable grave e insolvencia), así como la imposición de una responsabilidad a quienes por ley tienen el deber de advertir esas situaciones de alarma y de llevar la iniciativa para su solución.

En este sentido, el recurso a los fundamentos últimos de las instituciones y al sentido de las medidas legalmente dispuestas permite dejar sentadas una serie de afirmaciones que pueden servir como guía operativa para resolver las dudas que se plantean, como el armazón bajo el que construir una respuesta completa, armónica y congruente.

La tarea propuesta debe comenzar por aclarar que la Ley no configura la disolución social y el concurso de acreedores como soluciones completamente excluyentes entre sí ante una situación de crisis económica, como medidas irreconciliables, de manera que, una vez adoptada una, quede por completo cerrado el paso a la otra. $\mathrm{Ni}$ con carácter general puede hablarse de un absoluto antagonismo conceptual, ontológico ni funcional entre una y otra, ni la Ley establece prohibiciones específicas al respecto. Así, es perfectamente lícito que una sociedad en concurso de acreedores, incluso estando pendiente de cumplimiento un convenio, se disuelva y entre en liquidación societaria (por voluntad de sus socios o por concurrencia de alguna otra causa legal de disolución del art.363.I TRLSC). La única limitación impuesta en este apartado tiene que ver con la posibilidad de que el concurso haya iniciado ya una vía de solución a través de la apertura de la fase de liquidación concursal. $Y$ es que en ese supuesto la disolución se produce ipso iure (arts.145.3 LCo y 36I.2 TRLSC), sin que quepa acudir directamente a la aplicación de las reglas de liquidación societaria (arts.37I a 400 TRLSC), sino a las de la liquidación concursal (bajo la dirección de la administración concursal, ejerciendo como liquidadores), que tienen carácter preferente debido a los intereses en presencia (art.372 TRLSC). Paralelamente, no hay impedimento legal para que una sociedad disuelta y en liquidación societaria solicite la declaración de concurso y busque una solución global para el pago a sus acreedores ante la constatación de la insuficiencia patrimonial o como modo de asignar más eficientemente los recursos disponibles de cara a un posterior reparto del eventual sobrante entre sus socios.

Así pues, la aparente alternatividad entre disolución y concurso que se desprende de la presencia misma de dos disposiciones normativas que ofrecen soluciones ante situaciones de crisis económica extrema y, más en concreto, de las referencias textuales de los arts.363 a 367 TRLSC, no descansa sobre una radical incompatibilidad entre una y otra. Se debe, a mi juicio, a uno de estos dos motivos:

-a que, ante la concurrencia del desajuste contable grave y de la insolvencia, el legislador considera que cualquiera de estas dos medidas puede ser apta para resolver el problema; y por ello las sitúa en este 
contexto en plano de igualdad, de suerte que, sea cual fuere la adoptada, liberan a los administradores de la responsabilidad que se cierne sobre ellos;

-a que, pese a que puede hablarse en general de una coincidencia en el tiempo de los supuestos de hecho verificadores de una causa de disolución y del presupuesto objetivo para el concurso, hay matices distintivos entre ellos que hacen que, en realidad, no exista tal disyuntiva en plano de indiferencia entre las medidas a adoptar, sino que cada una de ellas sea la apropiada según qué casos; ante lo que habrá que concluir que la absoluta liberación de responsabilidad de los administradores solo se producirá cuando se haya optado por la opción legalmente considerada como acertada. Todo lo cual no impide, como se ha dicho, que, seleccionada la opción apropiada, y dados los primeros pasos para resolver el problema económico, no se pueda acudir después a la otra alternativa.

Discernir cuándo entra en acción la primera o la segunda de las explicaciones a la luz de la disciplina dispuesta por el legislador no resulta nada fácil. Pero, antes que nada, resulta oportuno recordar, por más que parezca obvia, una afirmación de la que puede extraerse una idea decisiva para resolver este dilema. La discusión sobre el carácter estrictamente disyuntivo del acuerdo de disolución y de la petición de concurso o de su indiferencia a la hora de resolver la crisis económica de la sociedad, así como, en cierta medida (y consecuentemente), sobre si las medidas pueden ser adoptadas en solitario por el órgano de administración o si se entra en el campo de actuación competencial de la junta general, únicamente existe cuando, simultánea y efectivamente, se dan los presupuestos requeridos para que se debata sobre ambos remedios. Si solo concurre la causa de disolución por pérdidas los arts.363 y ss TRLSC han de aplicarse prescindiendo de las referencias al concurso de acreedores, en el sentido de que la discusión girará en torno a la disolución de la sociedad o la adopción de alguna operación societaria que elimine de inmediato el desajuste grave entre patrimonio neto y capital. Tanto es así que la solicitud de concurso por el órgano de administración al amparo del art.3.I.2 LCo no solo debiera ser rechazada (por no haber insolvencia), sino que en modo alguno liberaría a sus miembros de la responsabilidad ex art.367 TRLSC. Y, de igual modo, si la insolvencia constatada no se ve acompañada de un desajuste contable grave en el sentido del art.363.I e) TRLSC, no habrá fundamento para que el órgano de administración plantee ante la junta general medida alguna, ni para que deba esperar a obtener la autorización de este órgano a acudir a la vía concursal para presentar la pertinente solicitud ante el Juez de lo Mercantil del domicilio social. En otras palabras: no será preceptiva la intervención de la junta a este respecto ni cabrá acudir a los arts.363 y ss. TRLSC (incluida la responsabilidad del art.367 TRLSC).

Como antes indiqué, no por ser irrebatible esta afirmación, debe dejar de destacarse, puesto que de ella deriva una conclusión muy importante a estos efectos. El instituto concursal persigue un objetivo rector; un interés del concurso que se describe como la búsqueda del mejor grado de satisfacción posible del conjunto de los acreedores concursales. Estando en presencia la consecución de ese objetivo, que se activa en cuanto se declara el concurso, no cabe idear soluciones que antepongan otros intereses, como serían los del conjunto de los socios. Quiere decirse que si la Ley deja paso a la voluntad de los socios expresada mediante un acuerdo de la junta general de la sociedad deudora para decidir cómo se resuelve la eventual concurrencia de causa de disolución y de insolvencia es porque considera que no hay (al menos por el momento) un interés superior que se imponga y que descarte que la iniciativa 
en la solución de ese problema esté en manos de los socios. Porque aún no se ha llegado al punto de tener que sobreponer el interés de los acreedores, puesto que en ese caso huelga acudir a la junta general.

Repárese en que el legislador mismo expresa esta idea, precisamente, en relación con el proceso conducente a la desaparición de la sociedad del tráfico, cuando el concurso avanza hacia su definitiva solución: no cabe aplicar las reglas de la liquidación societaria mientras esté en juego la liquidación concursal (art.372 TRLSC), por la sencilla razón de que aquellas no están dictadas para responder a los intereses preferentes de los acreedores, sino a los de los socios. $Y$ no porque la liquidación societaria prescinda de los intereses de aquellos, sino porque su estructura se construye sobre una premisa, ante cuya ausencia no cabe su juego: que hay patrimonio para pagar a todos los acreedores ${ }^{66}$. Si no lo hay, entonces lo que procede es varar la liquidación societaria y pedir el concurso.

Pues bien, este mismo argumento puede trasladarse al trance justamente previo a la declaración de concurso y servir de este modo para aclarar las dudas que pudieran suscitarse ante la coincidencia de un desajuste contable grave y la insolvencia de la sociedad. Si la opción de la disolución social y consiguiente entrada en fase de liquidación societaria solo debe plantearse en la medida en que no haya un interés superior al de los socios que se imponga (como sería el de los acreedores), parece de suyo lógico concluir que únicamente debe estar disponible cuando no existe un deber legal de acudir al concurso, ya que este deber vendría a representar la más clara manifestación legislativa de que, a partir de ese momento, y aunque aún no se haya declarado el concurso, deben tenerse en cuenta los intereses de los acreedores por encima de cualesquiera otros. A mi modo de ver, en consecuencia, la posibilidad de elección entre disolver y pedir el concurso solo tiene cabida en los casos de insolvencia inminente, en que aún no existe una obligación de pedir el concurso y el problema puede encontrar (la Ley así lo permitiría) una solución que tenga en cuenta, en igualdad de plano, el interés social ${ }^{67}$. En los casos de insolvencia actual tal paridad de intereses desaparece; en esa tesitura se impone ante todo [procede, siguiendo el verbo empleado por el legislador en el art.363.I e) TRLSC como fórmula excluyente de la "obligación" de disolver], y por encima de todo, dar solución a la incapacidad de pago. Por lo que debe ser el órgano de administración el que, en ejercicio de sus funciones, atienda el deber legalmente dispuesto al efecto y pida el concurso. Se trata, por otra parte, de una opinión que sí puede considerarse predominante en el seno de la doctrina, pese a la división que se aprecia en general en torno a toda esta materia (Alcover, 2006; Sequeira, 2009; Gallego, 2012a; Pulgar, 2012; Megías, 2015) ${ }^{68}$.

${ }^{66}$ De ahí que no se hallen en las normas sobre la liquidación societaria reglas la forma de llevar a cabo las enajenaciones de activos o sobre eventuales preferencias entre acreedores a la hora de proceder a los pagos. Y es que, estando en curso de saldar las deudas, y habiendo suficiente para satisfacerlas íntegramente, resulta indiferente el modo $u$ orden como se haga.

${ }^{67} \mathrm{Sin}$ ir más lejos, puede que la venta de determinados activos durante la fase de liquidación elimine de por sí la amenaza de incapacidad de pago que supone la insolvencia inminente.

${ }^{68}$ Cfr. igualmente, en la jurisprudencia, la Sentencia del Tribunal Supremo (Sala $1^{\text {a }}$, de lo Civil) de 15.10.2013: "[L]a propia sentencia recurrida reconoce que la causa de disolución invocada en la demanda que habría determinado el deber promover la disolución, cuyo incumplimiento justificaría la estimación de la acción de responsabilidad ex art. 262.5 TRLSA, era el "hecho de encontrarse -la sociedad-en situación de insolvencia". El estado de insolvencia no constituye, por sí, una causa legal que haga surgir el deber de los administradores de promover la disolución de la sociedad. No cabe confundir, como parece que hacen la demanda y la sentencia recurrida, entre estado 
En suma, el margen de actuación de la sociedad cuando su patrimonio neto se halla por debajo de la mitad del capital social existe solo cuando esta situación coincide con una insolvencia inminente (y mientras persista esa inminencia y no pase a ser $\left.a c t u a l^{69}\right)$. La Ley centra su atención a la hora de regular este asunto en el modo de proceder de la sociedad respecto de la disolución, vía acuerdo de la junta, vía resolución judicial subsidiaria previo expediente de jurisdicción voluntaria. Pero, además de la petición de concurso, existen otras alternativas funcionalmente aptas, como podrían ser todas aquellas que provoquen como efecto inmediato una remoción de la causa de disolución ( $y$ de la insolvencia, cabe entender): aumentos de capital social o reducciones y aumentos simultáneos de capital (la reducción por sí sola podría resolver el problema del desajuste contable, pero no el de la insolvencia), aportaciones de los socios a fondo perdido, transformación social, obtención de préstamos participativos conforme al Real Decreto-Ley 7/1996, fusiones por absorción, escisiones parciales y segregaciones, cesiones globales de activo y pasivo, etc. (Megías, 2015). Todas ellas tienen potencial virtualidad para eliminar el grave desajuste contable (también, al paso, la amenaza de insolvencia) sin disolver la sociedad ni extinguirla (aunque, desde luego, nada impediría que la solución consistiera en una fórmula de extinción social sin liquidación $)^{70}$. Eso sí; todas ellas deberán adoptarse siguiendo fielmente las reglas específicamente dispuestas para su licitud (sin olvidar las “meramente procedimentales", como son las que conciernen al anuncio de convocatoria de la junta general ${ }^{71}$ ), lo que, señaladamente, puede implicar,

de insolvencia y la situación de pérdidas que reducen el patrimonio neto de la sociedad por debajo de la mitad del capital social, que, como veremos a continuación, sí constituye causa de disolución. Aunque es frecuente que ambas situaciones se solapen, puede ocurrir que exista causa de disolución por pérdidas patrimoniales que reduzcan el patrimonio de la sociedad a menos de la mitad del capital social, y no por ello la sociedad esté incursa en causa de concurso. En estos supuestos opera con normalidad el deber de promover la disolución conforme a lo prescrito, antes en los arts. 262 TRLSA y 105 LSRL, y ahora en el art. 365 LSC. Y a la inversa, es posible que el estado de insolvencia acaezca sin que exista causa legal de disolución, lo que impone la obligación de instar el concurso, cuya apertura no supone por sí sola la disolución de la sociedad, sin perjuicio de que pueda ser declarada durante su tramitación por la junta de socios y siempre por efecto legal derivado de la apertura de la fase de liquidación (art. 145.3 LC)].No obstante, en supuestos en que concurra la causa $4^{a}$ del art. 260.1TRLSA [actual núm. 363.1.d) LSC], pérdidas que hayan reducido el patrimonio neto por debajo de la mitad del capital social, cesa el deber de instar la disolución si, por concurrir además el estado de insolvencia de la compañia conforme al art. 2.2 LC (cuando "no puede cumplir regularmente sus obligaciones exigibles"), se solicita y es declarado el concurso de acreedores de la sociedad. Asi se desprende de una interpretación del citado art. 260.1.4 TRLSA, en relación con los apartados 2 y 5 del art. 262TRLSA.[]Lo anterior no significa que la declaración de concurso de acreedores exima de la posible responsabilidad ex art. 262.5 TRLSA, en que los administradores hubieran podido incurrir antes del concurso, sin perjuicio de que, tras la reforma introducida por la Ley 38/2011, de 10 de octubre, la declaración de concurso suspenda el ejercicio de esta acción de responsabilidad (art. 50.2 LC) y, si se lo hubiera sido y estuviera en tramitación, se paralizará el procedimiento (art. 51.1.bis LC)".

${ }^{69}$ En ese caso procede, de nuevo, acudir a la solicitud de concurso por el órgano de administración, aunque ello pueda llevar consigo una desconvocatoria de la junta general (la alteración de las circunstancias bajo las que se convocó lo justificaría) o que se mantuviera la cita para la reunión pero determinados puntos del orden del día tuvieran que ser eliminados o sustituidos por un simple informe del órgano de administración sobre la situación reinante, los cambios producidos y las nuevas decisiones que han debido tomarse.

${ }^{70}$ Como sería el caso de la escisión total de la sociedad o de su absorción por otra.

${ }^{71}$ Téngase en cuenta que la reforma introducida por la Ley 31/2014, de 3 de diciembre, por la que se modifica la Ley de Sociedades de Capital para la mejora del gobierno corporativo (BOE $\mathrm{n}^{\circ} 293$, de 4 de diciembre de 2014) acomete una poda muy significativa de los motivos de impugnación de acuerdos que recaigan sobre el proceso de toma de decisiones por la junta, incluidos los "meramente procedimentales" (cfr. art.204.3 TRLSC). Bien es cierto que, sin perjuicio de que algunos de estos últimos se verifiquen en concurrencia con otro tipo de vicios que afecten a los derechos de participación de los socios (por ejemplo, una infracción del derecho de 
según los casos, una actuación más o menos intensa de uno u otro órgano social. Y, por supuesto, respetando el plazo legalmente establecido para convocar la junta general.

En cuanto a la responsabilidad de los administradores, razonable resulta concluir ( $y$ una interpretación restrictiva parece imponerse, por tratarse de una responsabilidad por deuda ajena) que debe ceñirse a (la ausencia, o falta de tino de) las decisiones propias tomadas en relación con la presencia de una causa legal de disolución, no a las que provengan exclusivamente de una decisión de la junta general, aunque para la efectividad de estas haya debido contarse con su ejecución ${ }^{72}$. La secuencia de actuaciones diseñada por el legislador societario en este punto implica un doble orden de decisiones autónomas o dos estadios en los que se requiere del órgano de administración un paso adelante específico: cuando se verifica la concurrencia de causa de disolución y de insolvencia (inminente); y cuando, transcurrida la fecha para la celebración de la junta, el problema continúa sin solución, sea cual fuere la causa. En ambos casos debe extremarse la diligencia de los administradores, tanto en la identificación en sí de los supuestos que abren paso a su iniciativa, como en la fijación de la medida a adoptar en consecuencia, siempre dentro de los plazos marcados.

En definitiva, la liberación de responsabilidad por el art.367 TRLSC no derivará del buen fin de las medidas adoptadas (de que de la disolución resulte la liquidación de todo el pasivo y la existencia de sobrante que repartir; de que el concurso acabe con convenio cumplido o con liquidación satisfactoria), sino del mero dato formal del acierto de sus decisiones (en cumplimiento de los mandatos legales) en torno a la causa legal de disolución. Es más, los administradores ni siquiera deben responder (se insiste, vía art.367 TRLSC; cuestión diferente puede ser, en su caso, por daños) por los acuerdos de la junta aparentemente aptos para resolver la situación de crisis pero de contenido diferente al que ellos hubieran propuesto, por desafortunados que acaben resultando ( $y$ aunque hayan tenido que participar en su ejecución), siempre que su propuesta se hubiera ajustado formalmente a la alternativa disponible conforme a Derecho ${ }^{73}$.

información en aspectos esenciales), entre estos defectos "meramente procedimentales" últimos siempre se dejan a salvo, como aptos para la impugnación de acuerdos, los de "carácter relevante".

${ }^{72}$ En ese caso parece que podría incurrirse en responsabilidad por los daños causados a la sociedad o a socios y otros terceros en ejecución de las decisiones de la junta (ex arts.236 a 241-bis TRLSC), pero no a la responsabilidad por deudas del art.367 TRLSC. Recuérdese, en este sentido, que el amparo, la instrucción o el mandato de la junta no autorizan al administrador a obrar contra la ley o los estatutos o infringiendo los deberes inherentes a su cargo, aunque, según las circunstancias, pudieran llegar a moderar el alcance de su responsabilidad por los daños causados (art.236.2 TRLSC).

${ }^{73}$ Bien es cierto que la complejidad en la adopción de acuerdos alternativos a la disolución social, que requiere disponer de una documentación e información exhaustivas que en la mayoría de los casos solo puede preparar el órgano de administración, reduce considerablemente la posibilidad de que la junta general apruebe válidamente una medida propuesta por sujetos distintos de los administradores. 


\section{Una propuesta de solución ante la alternativa legal entre la disolución social y el concurso}

Con todos los antecedentes expuestos, puede aventurarse una propuesta de solución al problema hermenéutico ocasionado por la imprecisa inclusión de la solicitud del concurso entre el catálogo de actuaciones a adoptar por la sociedad cuando se halle incursa en una causa de disolución por pérdidas [ex art.363.I e) TRLSC].

De entrada, la distinta relevancia de los intereses primordialmente en juego en caso de coexistencia de una causa de disolución por pérdidas y de una insolvencia parece llevar a la conclusión de que, cuando esta última sea actual ${ }^{74}$, el órgano de administración de la sociedad tiene el deber, cumpliendo la obligación legal establecida por el art.5 LCo y sin necesidad de acudir para ello a obtener el respaldo de la junta general (art.3.I.2 LCo), de pedir el concurso de la sociedad. Cualquier otra actuación sustitutoria que prescinda de la solicitud de concurso (por ejemplo, una convocatoria de junta para que acuerde la disolución) será considerada no "procedente", en los términos del art.363.I e) TRLSC. Otro tanto sucederá si una insolvencia tomada inicialmente como inminente deviene actual con posterioridad. Con independencia del curso que hayan venido tomando las actuaciones hasta ese momento, el órgano de gestión social -sea el de administración, sea el de liquidación si la junta hubiera acordado ya la disolución- deberá pedir el concurso voluntario (Alcover, 2006; Megías, 2015). Bien es cierto que en estos supuestos en que es preceptivo acudir al concurso de acreedores, $y$ aun contrariamente a lo que sostiene buena parte de la doctrina (Alcover, 2006; Bataller, 20I Ib; Gallego, 20I2b; Pulgar, 20I2) y a lo que la lógica del sistema debería conducir, no parece haber base legal para que entre en juego la responsabilidad por deudas de la legislación societaria impuesta por la inactividad de los administradores. Por sorprendente que pueda resultar, la Ley anuda la responsabilidad ex art.367 TRLSC, textualmente, al hecho de no convocar la junta para debatir sobre la disolución o al de no pedir del Juez dicha disolución o el concurso (en este trance sí) tras haberse frustrado la opción de un acuerdo de los socios. Nada se dice respecto del deber de pedir el concurso nada más apreciarse que había insolvencia actual y un desajuste contable grave, posiblemente porque desee ceñirse la mencionada responsabilidad por deudas al hecho de no efectuar un llamamiento a los socios ante la presencia de una causa legal de disolución [que formalmente se excluye si hay insolvencia actual, según se desprende del art.363 l.e) TRLSC] o a no darle la continuidad querida por la Ley una vez realizado dicho llamamiento y dada la pasividad de la junta general al respecto. En definitiva, tal vez se haya considerado suficiente (responsabilidades por daños aparte, ante la sociedad y ante terceros, ex arts.236 a 24I-bis TRLSC) con las consecuencias jurídicas que puede deparar para los administradores la inobservancia del deber de pedir el concurso en caso de insolvencia actual, si finalmente ese concurso se abre y se califica como culpable (arts. 172 y I72-bis LCo).

\footnotetext{
${ }^{74} \mathrm{Nada}$ impide, cabe pensar, que el órgano de administración pueda eliminar ambas amenazas (la causa de disolución y la insolvencia) mediante medidas bajo su exclusiva competencia, como la petición de préstamos participativos conforme al Real Decreto-Ley 7/1996 o la enajenación de algunos activos, en ambos casos no esenciales [cfr. art.160 f) TRLSC], mediante los que obtener las plusvalías contables y la liquidez precisa para salir del aprieto. En ese caso, desaparecido el supuesto de hecho del art.363.1 e) TRLSC, no será preciso acudir a la junta general ni habrá responsabilidad por deudas sociales.
} 
Así pues, en realidad, la alternativa entre la decisión de la junta general sobre la disolución o el concurso solo se plantea en los casos de insolvencia inminente, en que, comoquiera que la Ley no establece aún un deber de acudir al procedimiento concursal, la sociedad (sus órganos) dispone todavía de cierto margen de decisión para dar la respuesta que consideren más adecuada a sus intereses a la situación económica planteada. En este sentido, parece claro que los administradores tienen en ese caso el deber de convocar una junta general en un plazo de dos meses (una junta que bien puede celebrarse con carácter universal). También parece indiscutible que en el orden del día de esa junta ha de figurar necesariamente el planteamiento de la disolución social por pérdidas. Asimismo, es incuestionable que en ese mismo orden del día puede proponerse (o apuntarse como alternativa) cualquier otro tipo de operación de competencia ordinaria de la junta (art.160 TRLSC) mediante la que sacar a la sociedad del grave desequilibrio patrimonial y de la incapacidad de pago que se avecina sin necesidad de disolverla [en su caso, aumento de capital, reducción y aumento de capital simultáneos, modificaciones estructurales, transformación en otro tipo social, etc.], pues en definitiva se trata de otorgar a los socios la decisión sobre si retirar la sociedad del tráfico ante la desaparición de buena parte de sus inversiones en forma de aportaciones al capital o de buscar otra fórmula de recomposición del equilibrio patrimonial (o, al menos, de lograr que el patrimonio se sitúe a la altura de la mitad de la cifra de capital) y de la solvencia que permita "probar suerte de nuevo" y mantener la sociedad en explotación.

Lo que resulta más incierto (peligrosamente incierto, pues se halla en juego una rigurosa responsabilidad por deudas) es si los administradores deben incluir la propuesta de solicitud de concurso debido a la insolvencia inminente como medida a adoptar por la junta (alternativa, cuanto menos, a la disolución) o si tal inclusión resulta meramente potestativa, de tal modo que será el órgano de administración el que esté en disposición de elegir entre proponer a la junta la disolución o la remoción, añadir en el orden del día la posibilidad de la solicitud de concurso, o, directamente, pedir el concurso de la sociedad sin convocar junta general. Desde luego, en modo alguno debiera permitirse que la propuesta de solicitud de concurso se presentara como única solución a los socios, pues eso supondría tanto como privarles de la posibilidad de decidirse por la otra alternativa: la disolución, que, además, debe constar de manera específica en el orden del día para poder ser adoptada válidamente por la junta general ${ }^{75}$.

La lectura del precepto que contiene el deber de convocar parece inclinarse por el carácter preceptivo de tal propuesta de solicitud de concurso (art.365.I.I TRLSC ${ }^{76}$ ). Una respuesta que, en mi opinión, se acomodaría mejor a dos consideraciones que no pueden dejarse a un lado, y pese a que buena parte de la doctrina se inclina en ciertos aspectos por una tesis diferente (Alcover, 2006; Sequeira, 2009; Bataller, 20I la):

${ }^{75}$ Cabe insistir en que la omisión de referencia alguna en el orden del día a la medida a adoptar (en este caso la disolución) constituiría un defecto "meramente procedimental" "relevante", suficiente según la Ley para impugnar un acuerdo [art.204.3 a TRLSC], salvo que de las circunstancias muy excepcionales del caso en cuestión se pudiera deducir su intrascendencia (por ejemplo, porque pudiera acreditarse que los socios habían tenido ocasión de conocer igualmente por otros cauces ajenos a la convocatoria que la medida iba a plantearse en junta).

${ }^{76}$ Cfr. art.365.1.1 TRLSC: "[L]os administradores deberán convocar la junta general en el plazo de dos meses para que adopte el acuerdo de disolución o, si la sociedad fuera insolvente, ésta inste el concurso". 
- Que el hecho de que la petición de concurso se introduzca como un asunto a tratar por la junta general, cuando de suyo es una competencia reservada a la decisión del órgano de administración (art.3.I.2 LCo), ha de obedecer a que el legislador quiere que cualquier medida que se adopte sirva para resolver (en paralelo al desarrollo del proceso de liquidación si se acuerda la disolución; o de inmediato, si se trata de cualquier otra medida) tanto el desequilibrio patrimonial como la amenaza de falta de liquidez que se cierne sobre la sociedad. Y para ello es indispensable que los socios estén en disposición de conocer con exactitud la situación financiera de la entidad y puedan decidir con conocimiento de causa si con la medida que se le propone van a arreglar los desajustes patrimoniales y de tesorería o si resulta más apropiado acudir directamente al concurso, sin perjuicio de que más adelante se aborde una eventual disolución.

-Que la Ley legitima a todo socio, cualquiera que sea su participación, a exigir del órgano de administración la convocatoria de una junta general tanto si a su juicio hay causa de disolución como insolvencia, lo que da a entender bien a las claras de que se trata de una inclusión en el anuncio preceptiva $^{77}$. Si no fuera así, esta legitimación se hubiera configurado como un derecho de minoría, en paralelo al que permite al $5 \%$ del capital pedir que se convoque una junta general extraordinaria para deliberar sobre el asunto que se considere oportuno (art. 168 TRLSC).

Llegados a este punto, la Ley no impone a la junta general una determinada medida, sea la disolución, sea la solicitud de concurso, sea cualquier otra que remueva la situación. Pero del tenor de las normas aplicables sí que parece colegirse la obligación de tomar alguna decisión al respecto de entre las admisibles. Así daría a entenderlo el art.365.2 TRLSC, cuando dispone que " $[L] a$ junta general podrá adoptar el acuerdo de disolución o, si constare en el orden del día, aquel o aquellos que sean necesarios para la remoción de la causa". Dos puntualizaciones cabe efectuar aquí:

- En primer lugar, que, aunque la Ley no aluda al concurso, es evidente que se trata a estos efectos de una medida situada en plano de igualdad con la disolución y la que pueda remover la situación. De lo contrario este apartado resultaría completamente incongruente con la inclusión del concurso en el orden del día (ya se trate de una inclusión preceptiva, como acabo de defender, o potestativa). Da la impresión de que en este punto los redactores del Texto Refundido cometieron un olvido, al reproducir, con solo un matiz nuevo (el referente a la constancia en

el orden del día), la norma del originario art. 105.2 LSRL, que había sido dictado (en marzo de 1995) sin tomar en consideración la interferencia en la cuestión del Derecho Concursal. Naturalmente, el acuerdo favorable a la petición de concurso habrá de ser ejecutado por el órgano de administración, so pena de incurrir en responsabilidad. Ahora bien, este supuesto concreto no se halla previsto por la Ley, que castiga la inactividad de los administradores sumada a la de la junta general (art.367.I TRLSC), no pese a la correcta actuación de esta. De ahí que, por paradójico que resulte, tal vez solo quepa reclamar responsabilidad por daños, mas no por deudas, si nos aferramos a una interpretación

${ }^{77}$ Cfr. art.365.1.2 TRLSC: "[C]ualquier socio podrá solicitar de los administradores la convocatoria si, a su juicio, concurriera alguna causa de disolución o la sociedad fuera insolvente". 
restrictiva de la norma, que parece forzada por su carácter excepcional y su corte punitivo (Alcover, 2006): Bien es cierto que no se trata de una opinión pacífica (Sequeira, 2009).

- En segundo lugar, que, precisamente en relación a ese matiz nuevo introducido, cabe recordar que cualquier otra medida que se adopte debe estar previamente presentada (o propuesta) como eventual solución en el orden del día. Es más, dada la compleja y exhaustiva labor preparatoria de una documentación justificativa de la operación que tiene la mayoría de estas medidas de remoción (incluso en caso de junta universal con unanimidad de todos los socios en la adopción del acuerdo), resulta difícil de imaginar una propuesta de alguna de estas medidas que no provenga del órgano de administración; al igual que sería complicado pensar en un supuesto de omisión en el orden del día de la referencia a la operación de que se trate que no constituya un vicio "relevante" a efectos de impugnación del acuerdo [conforme al art.204.3 a) TRLSC]. De ahí que el acuerdo deba considerarse nulo si no consta en el orden del día, específicamente, y junto con la disolución o la petición de concurso, la propuesta de remoción concreta que se plantea (Bataller, 201 la) ${ }^{78}$.

Las afirmaciones realizadas explican que, si la junta no se convoca, no se celebra, o no adopta "alguno de los acuerdos previstos en el artículo anterior", se faculte a cualquier interesado para solicitar la disolución judicial de la sociedad (vía expediente de jurisdicción voluntaria: arts. I 25 a I 28 LJV). Conviene recordar que se trata de la única medida que "cualquier interesado" puede instar del Juez, pues ni esta cualidad basta de por sí para pedir un concurso necesario (cfr: art.3 LCo; por otro, lado, aún no cabría solicitarlo, si la insolvencia sigue siendo inminente) ni cabe imponer judicialmente ninguna otra operación societaria de remoción de la situación. Quede claro que la ausencia de celebración de la junta (puede que no se alcance el quórum legal o, en el caso de las sociedades anónimas, el establecido por los estatutos para ello ${ }^{79}$ ) o de adopción de alguno de los acuerdos propuestos no representan supuestos generadores de responsabilidad por deudas de los administradores, ya que estos habrán cumplido la primera fase de su preceptiva actuación con la convocatoria y la propuesta de las medidas que correspondan. Lo que sí hará nacer automáticamente es la segunda fase de sus deberes de actuación, también de dos meses de duración (a contar desde la fecha prevista para la reunión de la junta frustrada), encaminada a culminar lo que se ha propuesto infructuosamente a los socios.

Sucede, sin embargo, que una vez más la imprecisión en la redacción de las normas y la descoordinación entre los preceptos suscita la incertidumbre sobre el proceder concreto que se exige de los administradores y la manera como pueden eludir la responsabilidad por deudas. Los arts.366.2.2, in

${ }^{78}$ Precisamente por lo que acaba de apuntarse en el texto no parece lícito que el orden del día incluya expresiones genéricas como "adopción del acuerdo de disolución por pérdidas, de solicitud de concurso de acreedores o cualquier otra medida que remueva la causa de disolución y de la insolvencia que resulten viables y puedan adoptarse".

${ }^{79}$ En principio, a efectos de la constitución de la junta general y de la adopción de los acuerdos, la disolución y la petición de concurso han de considerarse acuerdos "ordinarios", para los que resulta suficiente con los quórums y mayorías de votación legales menos exigentes (cfr. arts.193-194 y 198 a 201 TRLSC). Todo ello con la salvedad de que pueda haber un refuerzo estatutario para los mismos, o sin perjuicio de que no se llegase al mínimo exigido para tratar de las medidas de remoción, que suelen requerir quórums y mayorías legales reforzados. 
fine, y 367.I, in fine, TRLSC insisten en que el deber de los administradores se reactiva (aparte de cuando no se celebra la junta) cuando "no se hubiera adoptado" acuerdo alguno o se hubiera aprobado uno "contrario a la disolución”. Ambas expresiones deben interpretarse armónicamente, entre sí y con el significado atribuido anteriormente al catálogo de acuerdos que puede adoptar la junta general. Como se ha dicho, la Ley quiere algún acuerdo que resuelva el desequilibrio contable y la insolvencia. Cuanto menos, la disolución. Y por eso la Ley se centra exclusivamente en ella. Pero, si se quiere, en vez de la disolución, tanto vale cualquier otro acuerdo que reúna la cualidad que se ha indicado. De modo que no adoptar acuerdo o adoptar uno contrario a la disolución deben interpretarse en el sentido de que el deber de actuación de los administradores renace ante cualquier supuesto que mantenga la situación de partida tal cual, esto es: a) la falta de sometimiento a votación de ninguna solución al respecto; $b$ ) la aprobación de una medida que sobre el papel deba estimarse indiscutiblemente ineficaz a los propósitos perseguidos; c) la no aprobación de ninguna de las medidas eficaces, normalmente derivada de una falta de la mayoría legalmente requerida para ello. La referencia al "acuerdo contrario a la disolución" se correspondería más bien con la hipótesis b) de las tres contempladas. Pero, en particular, en el art.367.I, in fine, TRLSC (en que solo se contempla esta posibilidad junto con la de que la junta no se haya constituido) parece tomar un significado más amplio, que englobaría igualmente a la hipótesis c), aunque, en puridad, cuando no se alcanza la mayoría legal o estatutariamente exigida, lo que hay es más bien un supuesto de no acuerdo de disolución (de concurso o de cualquier otra medida de remoción $)^{80}$.

La actuación requerida de los administradores va en consonancia con la pretendida de la junta. Si en el abanico de opciones puestas a disposición de la junta general las operaciones de remoción de la situación eran de inclusión en el orden del día completamente potestativa; si el concurso, estando en insolvencia inminente, era de inclusión preceptiva pero de adopción potestativa; y si la disolución constituía la medida de planteamiento necesario y de adopción igualmente imperativa en caso de no alcanzarse ninguna de las anteriores (a fin de no traicionar más la confianza del tráfico en un patrimonio libre de deudas equivalente a la cifra del capital y de ir allegando los recursos necesarios mediante la enajenación de los activos al objeto de atender los pasivos a sus respectivos vencimientos), será la disolución social la medida que deberá instarse del Juez de lo Mercantil. A falta de algún acuerdo válido al respecto de la junta general, la petición de concurso debe ceder ante la disolución mientras la insolvencia sea inminente (sin perjuicio, claro está, de que con posterioridad dicho concurso pueda pedirse por los liquidadores). Por este motivo aquella petición queda descartada mientras la insolvencia

${ }^{80}$ El "acuerdo contrario" es una expresión recurrente en el articulado del TRLSC (cfr. en materia de amortización de la autocartera, arts.139.3.1, in fine; o acerca del ejercicio de la acción social de responsabilidad contra los administradores por parte de la minoría, art.239.1.1, in fine, TRLSC), que debiera entenderse como se hace en el texto (esto, incluyendo los casos de no acuerdo) atendiendo a la finalidad de los preceptos en que se recogen, que imponen o habilitan a una actuación por una instancia de decisión distinta de la junta general, cuando esta no ha aprobado un acuerdo con un contenido concreto. Por lo tanto, permitir esa actuación solo en los supuestos (poco ortodoxos) de que haya habido un acuerdo explícitamente desfavorable a determinada medida (esto es, una propuesta de dejar las cosas como estaban antes de la junta, para lo que en verdad que no se precisaría acuerdo alguno) provocaría una reducción injustificada del alcance de las normas. 
no se torne en actual, supuesto en el que se produce una inversión del juego de las alternativas, pasando a ser la opción preferente.

Por último, hay que recordar que los administradores pueden incurrir en responsabilidad por deudas ajenas, pero en todo caso como consecuencia de actos propios, de errores $u$ omisiones cometidos en el cumplimiento de sus deberes en relación con la presencia de una causa de disolución, y (habida cuenta de la naturaleza de la norma contenida en el art.367 TRLSC) siempre que la infracción cometida se halle explícitamente sancionada con dicha responsabilidad. Así, por ejemplo, se responderá por pedir el concurso sin que realmente hubiera insolvencia. Esto es: por la desestimación de la petición de concurso formulada sobre la base de una inadecuada apreciación de un estado de insolvencia actual -o la revocación del auto declarativo-, cuando hubiera correspondido convocar a los socios para acordar la disolución o alguna otra medida de respuesta a la crisis económica. Pero no por iniciar los trámites para disolver o remover la causa cuando la sociedad estaba en una situación de insolvencia actual y no cabía ya plantear otra alternativa lícita que no fuera la solicitud de concurso, dado que en ese caso no existía causa de disolución y no entraba en juego el régimen del art.367 TRLSC ${ }^{81}$. Tampoco se responderá, a mi juicio, por la declaración de nulidad del acuerdo de la junta general de disolución al entenderse inexistente la causa alegada, por más que se estuviera en insolvencia inminente, ya que esta última, considerada en solitario, ni constituye a los administradores en el deber de pedir el concurso ni requiere por sí misma una reunión de la junta general.

Sentado lo anterior, una vez puestos en funcionamiento correctamente los mecanismos precisos para dar solución a la crisis económica presentada mediante una de las medidas dispuestas por el legislador, no procede volver a plantear la alternativa como fuente de deberes de actuación de los administradores al respecto y como eventual desencadenante de una responsabilidad por deudas (ex art.367 TRLSC). Es normal que, iniciado el proceso de liquidación, persistan tanto el desajuste contable grave como la insolvencia inminente (atemperada si acaso por la suspensión momentánea del pago de los créditos concursales hasta que se atisbe una solución), puesto que ninguna de las dos encuentra solución de inmediato con la disolución social ${ }^{82}$. Luego plantear de nuevo los deberes de los administradores y las consecuencias de su incumplimiento resultaría absurdo, pues conduciría a un bucle que imposibilitaría a la postre evitar la responsabilidad por deudas. Otro tanto sucedería con el supuesto opuesto: que, declarado el concurso, sin haber concluido aún el procedimiento, se siga en insolvencia (sería lo normal; el concurso está para resolverla, pero su apertura no implica automáticamente su eliminación) y en situación de causa de disolución por pérdidas ${ }^{83}$. Con todo, probablemente sí sería admisible tal

${ }^{81}$ Lo que no quita que, por concurrir un incumplimiento del deber legal de pedir el concurso, en su caso, los administradores puedan verse catalogados como personas afectadas por la calificación como culpable del concurso que eventualmente pueda dictarse, con las consecuencias dispuestas por los arts.272 y 272-bis LCo. Y todo ello sin perjuicio de la responsabilidad por los daños eventualmente causados a la sociedad y a terceros (señaladamente, los acreedores) en que podrían haber incurrido por su pasividad cuanto menos negligente.

${ }^{82} \mathrm{Si}$ la insolvencia pasa a ser actual el órgano de administración deberá pedir el concurso, pero sin verse sujeto a la responsabilidad del art.367 TRLSC ante su incumplimiento, pues para ello sería preciso que simultáneamente estuviera pendiente de adopción alguna medida en respuesta a la causa de disolución por pérdidas, que precisamente ya estaría tomada.

${ }^{83}$ Así lo expresó el Tribunal Supremo -Sala 1"a de lo Civil- en STS 15.10.2013: "No obstante, en supuestos en que concurra la causa $4^{a}$ del art. 260.1 TRLSA [actual núm. 363.1.d) LSC], pérdidas que hayan reducido el patrimonio 
planteamiento, constante el concurso, siempre que, una vez declarado, sobreviniera ex novo otra causa de disolución (incluso la disolución por pérdidas si con anterioridad, constante el concurso, la originaria hubiera sido eliminada $)^{84}$.

\section{La interferencia del artículo 5-bis de la ley concursal en el ámbito de aplicación de la disciplina}

La profundidad de la crisis económica que ha azotado al tráfico empresarial español desde finales de la década pasada, y su indudable antecedente en un acusado déficit de financiación en el mercado, han llevado al legislador a corregir el planteamiento inicial de la Ley Concursal para recoger en su articulado, vía sucesivas y no siempre bien coordinadas reformas, expedientes que, con independencia de que los deudores se hallen o no en insolvencia (las más de las veces, lo estarán -o deben estarlo para acogerse a ellos-), pretenden ante todo buscar fórmulas que permitan inyectar recursos financieros en las empresas consideradas económicamente viables eludiendo la entrada en concurso de acreedores (con los efectos perniciosos que puede conllevar, especialmente en un clima generalizado de impagos) o, si acaso, si la declaración de concurso resulta inevitable finalmente, protegiendo la posición de quienes en estas etapas preconcursales se avienen a conceder crédito al deudor para intentar salvar la empresa.

neto por debajo de la mitad del capital social, cesa el deber de instar la disolución si, por concurrir además el estado de insolvencia de la compañía conforme al art. 2.2 LC (cuando "no puede cumplir regularmente sus obligaciones exigibles"), se solicita y es declarado el concurso de acreedores de la sociedad. Así se desprende de una interpretación del citado art. 260.1.4 TRLSA, en relación con los apartados 2 y 5 del art. 262 TRLSA. [LL anterior no significa que la declaración de concurso de acreedores exima de la posible responsabilidad ex art. 262.5 TRLSA, en que los administradores hubieran podido incurrir antes del concurso, sin perjuicio de que, tras la reforma introducida por la Ley 38/2011, de 10 de octubre, la declaración de concurso suspenda el ejercicio de esta acción de responsabilidad (art. 50.2 LC) y, si se lo hubiera sido y estuviera en tramitación, se paralizará el procedimiento (art. 51.1.bis LC).】 JSin embargo, sí supone que, tras la declaración de concurso, cesa el deber legal de los administradores de instar la disolución, que se acordará finalmente, como un efecto legal de la apertura de la fase de liquidación (art. $145.3 \mathrm{LC}$ ), cuando se opte por esta solución concursal. Que cese este deber legal de promover la disolución de la sociedad, mediante la convocatoria de la junta de accionistas para que adopte el preceptivo acuerdo, no significa que la junta de accionistas no pueda acordarlo, pues está perfectamente legitimada para hacerlo sin que deba necesariamente concurrir una causa legal para ello (art. 260.1.1 ${ }^{\circ}$ TRLSA ). [T Tampoco durante la fase de cumplimiento del convenio puede surgir el deber de promover la disolución y la consiguiente responsabilidad por no hacerlo dentro del plazo legal. Lo impide, no la vigencia de los efectos de la declaración de concurso, que cesan conforme al art. 133.2 LC, sino la propia normativa societaria (en nuestro caso, los arts. 260.1.4 ${ }^{\circ}$ y 262.2 y 5 TRLSA), que establece el concurso de acreedores como un limite al deber de los administradores de promover la disolución, bajo la lógica de que la situación de concurso de la compañia se rige por una normativa propia, que expresamente prevé la disolución de la compañía, como consecuencia necesaria a la apertura de la fase de liquidación (art. 145.3 LC), y que, en caso de aprobación de convenio, impone al deudor el deber de instar la liquidación cuando, durante la vigencia del convenio, conozca la imposibilidad de cumplir los pagos comprometidos y las obligaciones contraídas con posterioridad a su aprobación (art. 142.2 LC)".

${ }^{84}$ Pienso, por lo tanto, que las afirmaciones contenidas en la Sentencia, citada en la Nota anterior, deben limitarse al tipo de supuestos de hecho en ella analizado, pero no a este que ahora se contempla, en el que la causa de disolución habría nacido durante el concurso. (por ejemplo, en fase de ejecución de un convenio; $\mathrm{y}$, por supuesto, sin que ello prive de contenido a la norma que exige del deudor que pida la apertura de la liquidación concursal cuando sea conocedor de que se haya ante una situación de reinsolvencia -art.142.2 LCo-) Con todo, mientras la sociedad este en concurso, no cabe reclamar de los administradores ex art.367 TRLSC (art.50.2 LCo). 
Se trata de expedientes que, aunque en estrictos términos formales y sustantivos no pueden considerarse "concursales", son susceptibles de llevar consigo algunos de los efectos beneficiosos de que "disfrutaría" un deudor en aras del interés del concurso, como la suspensión de juicios ejecutivos o la adopción de soluciones convenidas con arrastre (esto es, a grandes rasgos: con vinculación de una amplia porción del pasivo -incluido, en su caso, el privilegiado- aun sin contar con el consentimiento de cada acreedor afectado, bastando para ello con la conformidad de los titulares de una mayoría de los créditos). En este sentido, se habla de expedientes pre o paraconcursales (Rodríguez de Quiñones, 2016): son los acuerdos de refinanciación (art.7I-bis LCo), el acuerdo de refinanciación homologado (DA $4^{\mathrm{a}}$ LCo) y el acuerdo extrajudicial de pagos (arts.23I a 242-bis LCo).

En lo que ahora nos ocupa, la principal virtualidad de estos expedientes viene expresada en el art.5-bis LCo, que declara automáticamente enervado el deber de pedir el concurso en caso de insolvencia actual (que quedará "sustituido" por otro deber, mensual, a los tres meses de neutralizarse el anterior, si persiste la insolvencia: art.5-bis.5 LCo) desde el momento en que el deudor (su órgano de administración) comunique al Juzgado de lo Mercantil que ha iniciado negociaciones para alcanzar un acuerdo de refinanciación de los previstos en el artículo 7l bis. I y en la Disposición adicional cuarta, o para obtener adhesiones a una propuesta anticipada de convenio en los términos previstos en la Ley. $O$, en el caso en que solicite un acuerdo extrajudicial de pagos, una vez que el mediador concursal propuesto al efecto acepte el cargo, en cuyo caso el registrador mercantil o el notario al que se hubiera solicitado la designación de dicho mediador concursal comunicará, de oficio, la apertura de las negociaciones al juzgado competente para la declaración de concurso. A la vista de tal artículo, surge la duda acerca de en qué medida puede incidir esta comunicación y la pertinente descarga del deber de solicitar el concurso sobre las actuaciones que los arts.363 y ss TRLSC reclaman de la sociedad en caso de concurrencia de una situación de insolvencia con la causa de disolución por pérdidas. Una cuestión sobre la que nada dice el legislador.

Para resolver este nuevo interrogante estimo preciso tener en cuenta las dos siguientes consideraciones:

- El art.363 TRLSC vincula la causa de disolución social con la situación de insolvencia, no con la solicitud misma de concurso. $Y$ tal situación de insolvencia estaría presente con el recurso al alguno de los expedientes pre o paraconcursales a que se refiere el art.5-bis LCo, por más que con su activación cese el deber de petición del concurso. Las comunicaciones del art.5-bis LCo, por consiguiente, no tendrían por qué incidir sobre el juego competencial entre el órgano de administración y la junta general que se desprenda de la disciplina legal, sea cual fuere este. Repárese, a mayor abundamiento, que, de sostenerse que las comunicaciones del art.5-bis LCo eliminan ese juego, quedaría siempre en manos del órgano de administración esquivar cómodamente la aplicación de lo dispuesto en los arts.363 y ss TRLSC y escapar al control de la junta general, pues, presupuesta la insolvencia, bastaría con acudir motu proprio a unos expedientes para los que la Ley no establece requisito sustancial añadido alguno.

- El recurso al art.5-bis LCo supone tanto como reconocer las dificultades financieras por las que atraviesa la sociedad (muy cercanas, cuando no plenamente indicativas de la insolvencia actual) e iniciar un camino hacia la petición de concurso que carece de punto de retorno, salvo que se alcance el acuerdo 
que se anuncia perseguir y se pase a ser solvente. Por ello, si su planteamiento coexiste con una causa de disolución por pérdidas, lógico será que su puesta en marcha se vea sometida a idéntico régimen que la solicitud de concurso propiamente dicha, de tal suerte que la aplicación de la disciplina establecida al efecto por los arts.363 y ss TRLSC (y complementada por la LCo) se mantenga inalterable.

En consecuencia, a mi modo de ver, cuando haya insolvencia, el régimen relativo a las comunicaciones del art.5-bis LCo debería quedar integrado sin más en la disciplina sobre la coexistencia del presupuesto objetivo del concurso con la causa de disolución por pérdidas. El órgano competente para tomar la decisión al respecto debiera ser el mismo que lo sería de no disponer del recurso el art.5-bis LCo, en los términos señalados en los epígrafes precedentes, y teniendo presente por ello la responsabilidad por deudas en juego de los administradores en el caso de pasividad o actuación contraria a lo legalmente ordenado según cada caso, siempre que esté presente una causa de disolución social. Esto es:

- Si la insolvencia fuera actual, y dado que la Ley no permite más demora en la actuación del deudor en protección de los intereses de los acreedores, sería el propio órgano de administración el que tendría la competencia, en solitario, para decidir acudir a alguno de los expedientes que abren paso al art.5-bis LCo o al concurso voluntario de la sociedad; no hay causa legal de disolución ni, por consiguiente, tampoco habrá margen para plantear una responsabilidad de los administradores ex art.367 TRLSC en caso de que no adoptaran ninguna de las medidas legalmente aptas al efecto.

- En cambio, si la insolvencia solo fuera inminente, deberá acudirse a la junta general para que sea esta la que tome la determinación de que se solicite acogerse al art.5-bis LCo, pedir el concurso voluntario, iniciar el proceso de salida del tráfico mediante la disolución y liquidación societarias o buscar alguna otra fórmula a través de la que remover la causa de disolución y resolver las dificultades financieras de la sociedad. De lo contrario se incurrirá en la responsabilidad por deudas del art.367 TRLSC.

\section{Lista de referencias}

Alcover, G. (2006). El ámbito de responsabilidad de los administradores en los nuievos artículos 262.5 de la Ley de Sociedad Anónima y 105.5 de la Ley de Sociedades de Responsabilidad Limitada, Revista de Derecho de Sociedades, I (26), 85-93

Bataller, J. (20I la). Deber de convocatoria (art.365). En A. Rojo y E. Beltrán (dirs.), Comentario de la Ley de Sociedades de Capital, tomo II (pp.2563-2568). Cizur Menor: Thomson-Reuters

Bataller, J. (20l l b). Responsabilidad solidaria de los administradores (art.367). En A. Rojo y E. Beltrán (dirs.), Comentario de la Ley de Sociedades de Capital, tomo II (pp.2572-2578). Cizur Menor: Thomson-Reuters

Beltrán, E. (2004). Reforma de la Ley de Sociedades Anónimas (Disposición Final Vigésima). En A. Rojo y E. Beltrán (dirs.), Comentario de la Ley Concursal, tomo II (pp.3240-3257). Madrid: Civitas

Gallego, E. (2012a). Concurso de la persona jurídica. En E. Beltrán y J.A. García-Cruces (dirs.), Enciclopedia de Derecho Concursal, tomo I (pp.59I-6I4). Cizur Menor: Thomson-Reuters

Gallego, E. (20I2b). Responsabilidad de los administradores. En E. Beltrán y J.A. García-Cruces (dirs.), Enciclopedia de Derecho Concursal, tomo II (pp.2643-2658). Cizur Menor: Thomson-Reuters 
Megías López, J. (2015). Competencia orgánica y crisis económica de sociedades de capital: disolución, preconcurso y concurso, Revista de Derecho Concursal y Paraconcursal, I (22), 443-456

Pulgar, J. (20I2). El presupuesto objetivo del concurso de acreedores. En J. Pulgar (dir.), El concurso de acreedores (pp. I47-192). Madrid: La Ley

Rodríguez de Quiñones, A. (2016). Derecho Concursal, en G. Jiménez y A. Díaz (coords.), Lecciones de Derecho Mercantil (pp.75I-900). Madrid: Tecnos (19a edición)

Rojo, A. (2004). Legitimación (art.3). En A. Rojo y E. Beltrán (dirs.), Comentario de la Ley Concursal, tomo I (pp. 194-224). Madrid: Civitas

Sequeira, A. (2009). Acuerdo social de disolución. En I. Arroyo, J.M. Embid y C. Górriz (coords.), Comentario a la Ley de Sociedades Anónimas, volumen III (pp.2506-2527). Madrid: Tecnos (2a edición)

Uría, R., Menéndez, A., y Beltrán, E. (1998). Disolución y liquidación de la sociedad de responsabilidad limitada. En R. Uría, A. Menéndez y M. Olivencia (dirs.), Comentario al régimen legal de las sociedades mercantiles, tomo XIV, vol.4 $4^{\circ}$ Madrid:Civitas

Vázquez Cueto, J.C. (2009). El presupuesto objetivo del concurso, Revista de Derecho de la Universidad Católica de la Santísima Concepción (Chile), 2(20), 91

Vázquez Cueto, J.C. (20I4). La calificación del concurso. En G. Jiménez y A. Díaz(coords.), Derecho Mercantil, Derecho Concursal, tomo 10 (pp.507-530). Madrid-Barcelona-Buenos Aires-Sao Paulo: Marcial Pons 